\author{
UNIVERSITY OF CALIFORNIA \\ COLLEGE OF AGRICULTURE \\ AGRICULTURAL EXPERIMENT STATION \\ BERKELEY, CALIFORNIA
}

\title{
THE TANK-MIXTURE METHOD FOR DORMANT OIL SPRAYING OF DECIDUOUS FRUIT TREES \\ IN CALIFORNIA
}

ARTHUR D. BORDEN

\section{BULLETIN 579}

JULY, 1934 


\section{CONTENTS}

Qualities of oil spray _. . . . . . . . . . 4

Commercial oil emulsions _. . . . . . . . . 5

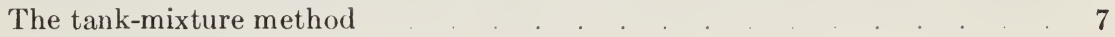

Oils employed . . . . . . . . . . . . . . . . . . . . . . . . . . 8

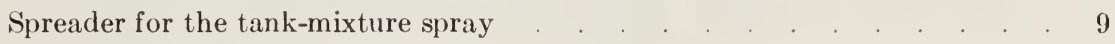

Spray-tank agitation . . . . . . . . . . . . . . . . . . . . . 9

Orchard experiments in the season of 1931-32 _ . _ . . . . . . . . . . 14

Orchard experiments in the season of 1932-33 _ . . . . . . . . . . . . 16

Results of 1932-33 orchard experiments . . . . . . . . . . . . . 16

Dosage recommendations . . . . . . . . . . . . . . . . . . . 20

San Jose scale . . . . . . . . . . . . . . . . . . . . . . . . . 20

Brown apricot scale . . . . . . . . . . . . . . . . . . . . . . . 20

Fruit tree leaf roller egg masses . . . . . . . . . . . . . . . . . 20

Brown mite eggs . . . . . . . . . . . . . . . . . . . . 20

Summary . . . . . . . . . . . . . . . . . . 20 


\section{THE TANK-MIXTURE METHOD FOR DORMANT OIL SPRAYING OF DECIDUOUS FRUIT TREES IN CALIFORNIA ${ }^{1,2}$}

ARTHUR D. BORDEN ${ }^{3}$

Marked advancements have been made during the past ten years in the use of dormant oil sprays in the spraying of deciduous fruit trees in California. The order of progress has included crude-oil emulsions, mechanical mixtures, distillate emulsions, miscible oils, and finally the paste-type emulsions in general use at the present time.

The fact is well established that oil spray is superior to liquid limesulfur solutions in the control of San Jose scale (Aspidiotus perniciosus Comst.) and other scale insects, and also that it is very effective in destroying the egg masses of the fruit tree leaf roller (Cacoecia argyrospila Walk.). The penetrating and spreading characteristics of the oil insures better results than can be obtained with the lime-sulfur wash. In addition to being more effective, oil sprays are easier to handle and apply, and cost less than lime-sulfur.

Crude-oil emulsions and miscible-oil emulsions are now rarely if ever used on deciduous fruit trees in California. The paste-type emulsions have replaced these and have advantages such as safety, economy, and ease of handling. But with this progress have come new problems pertaining to the type of oil and the kind and amount of emulsifier required to give the most satisfactory results. Since attention has been paid to the type of oil used in the emulsions and the oil-depositing quality of the spray, the chance of injury to dormant deciduous trees is small. The safety of the dormant spray oils is largely dependent upon the sulfonation and the viscosity of the oils. The only precautions now practiced in the use of dormant oil sprays are that the early applications are not made before the trees are dormant nor before enough rain has fallen in the early winter to wet the soil sufficiently, and that the late applications are not made after the "green tip" stage of the bud. In general, in northern California the dormant sprays are applied in the months of January and February.

1 Received for publication November 23, 1933.

2 The writer wishes to express his appreciation to E. L. Wampler, graduate student in Entomology, for his assistance in these experiments.

3 Assistant Entomologist in the Experiment Station. 
The fruit grower is often confused by the many brands of emulsions offered him and by the claims made by some salesmen. Too frequently the price alone may be the deciding factor. Seasonal changes in the formulas by the manufacturers, and a change of brands by the growers are often responsible for notable differences in efficiency. These, together with the ever present difficulty of obtaining sufficient coverage in making the application, may prevent satisfactory control.

\section{QUALITIES OF OIL SPRAY}

There are certain special terms used in describing oil sprays which may be explained at this point.

Spray oils are one type of product obtained in the distillation and purification of crude oil. The crude oil is placed in stills and, under partial vacuum, is heated to successively higher temperatures. Spray oils are the less volatile fractions which come over after the lighter stove distillates and before the heavier lubricating oils.

The purification process is accomplished by removing the undesirable unsaturated and aromatic hydrocarbons, which are regarded as impurities, by treating the distillate with liquid sulfur dioxide or after subsequent treatment with strong sufuric acid. The unsaturated and aromatic compounds are removed as a heavy dark sludge. The purified oil is neutralized by washing with an alkaline solution and is then thoroughly washed with water. It is later dried by blowing air through the oil.

The unsaturated and aromatic hydrocarbons are particularly injurious to trees, and therefore the safety of an oil depends on the extent to which these compounds are removed. The purity of a spray oil is determined by the percentage that remains unchanged when subjected to the sulfuric acid test, known as the sulfonation test. Dormant spray oils generally show an unsulfonation of from 60 to 74 per cent.

Spray oils have been classified as light, light-medium, medium, and heavy, on the basis of viscosity and distillation. The viscosity pertains to the flow of the oil and is expressed as the number of seconds required for 60 cubic centimeters at a temperature of 100 degrees Fahrenheit to flow through a small orifice in an instrument known as the Saybolt Universal viscosimeter.

The distillation range gives the minimum and maximum temperatures between which the distillation takes place and the percentage of oil distilling over at certain temperatures within the range.

A "straight-cut" oil is one derived from distillation within certain definite ranges of temperatures and is not a blended oil. 
Blended oils are those in which an oil of a lower viscosity and distillation range has been mixed or blended with one of a higher viscosity and distillation range. The viscosity of such a blended oil is not particularly indicative of the properties of such a product. The distillation reveals the nature of such an oil.

A spray oil emulsion usually consists of from 80 to 85 per cent spray oil, which has been formed into a stiff paste by the addition of an emulsifier and water. The common emulsifiers used are ammonia caseinate, petroleum soaps, etc. The use of such emulsifiers usually insures the stability of the emulsion and the suspension of the oil particles when diluted in water. In general there are two types of emulsions : the quickbreaking and the "tight" emulsion. In the former type a minimum amount of emulsifier is used and the oil globules are less securely held in the dilute spray so as to produce a higher percentage of oil deposit when the spray strikes the bark or foliage of a tree. This type is more desirable and efficient than the more stable emulsions called tight emulsions, in which the oil droplets are more securely held by the emulsifier and deposit comparatively low percentages of oil.

The oil-depositing, wetting, and spreading properties of any spray are of much importance. A spray may overcome the resistance of the bark or foliage of a tree to wetting and yet deposit but comparatively little oil. Much of the oil may be lost in the runoff, or drip, from the tree. On the other hand, a minimum amount of wetting and spreading is essential to give a quick, even distribution of the oil deposited.

\section{COMMERCIAL OIL EMULSIONS}

In northern California at present, nearly a score of commercial oil emulsions are offered to the growers for use in the dormant sprays. Many of these are excellent emulsions made from refined lubricating oils with different types of emulsifiers. The results of studies indicate that some of these emulsions contain undesirable blends of oils, while others are made from oils that are too low in purity. The greatest difficulty lies in the wide variance in the oil-depositing properties of the different emulsions. The so-called "tight" emulsions deposit a very low percentage of oil and allow too much of the oil to be lost in the runoff. Other emulsions of a quick-breaking type deposit a comparatively heavy film which is much more desirable.

The oil-depositing quality of the spray bears an important relation to the dosage of oil that is required to give effective control. This quality is determined by the kind and amount of emulsifier contained in the emulsion or the spray mixture in the tank. Manufacturers of emulsions have apparently given this important point but little consideration. 
The results of laboratory tests on the amount of oil deposited on 25 square inches of waxed surface by 14 brands of commercial oil emulsions are shown in table 1 . In each test the spray was a 5 per cent emulsion. Each test was repeated ten times in order to obtain an average which may be regarded as reasonably correct. The exposure to the spray was for 15 seconds.

In table 1 the wide variation in the oil-depositing properties of the commercial oil emulsions is shown. Emulsion No. 13, which shows the lowest oil deposit, is sold for the same purposes and is recommended to

TABLE 1

Oil Deposits of Commercial Oil Emulsions

\begin{tabular}{c|c||c|c}
\hline \hline Brand No. & $\begin{array}{c}\text { Oil deposit } \\
\text { in milligrams }\end{array}$ & Brand No. & $\begin{array}{c}\text { Oil deposit } \\
\text { in milligrams }\end{array}$ \\
\hline 1 & 33 & 8 & 47 \\
2 & 24 & 9 & 28 \\
3 & 25 & 10 & 42 \\
4 & 37 & 11 & 40 \\
5 & 55 & 12 & 23 \\
6 & 51 & 13 & 22 \\
7 & 54 & 14 & 48 \\
\hline
\end{tabular}

be used at the same dosage as emulsion No. 5, which shows the highest deposit. A manufacturer may sell three or more brands of emulsions to be used at the same dosage, and yet the emulsions may differ widely in oil deposits.

The changing of the type or amount of emulsifier used in the manufacture of emulsions naturally changes the properties of the emulsion. These changes may sometimes occur during a season, and the user of the material may not be aware of the difference in the product.

At the request of deciduous fruit growers in northern California, the investigation of dormant oil emulsions was begun in 1930 by the University of California to determine what type of an emulsion gives the highest efficiency, and why more uniform results are not obtained in the orchard.

The success of the tank-mixture method in spraying citrus trees in southern California was very marked, and its application to deciduous fruit trees in northern California remained a comparatively new field. An earlier attempt to use certain oil and calcium caseinate spreader without proper agitation in Santa Clara County had started a few growers to use these materials, but much more study was necessary to make it a safe practice. The economic situation in the fruit industries also made it necessary to lower costs of insect control. A solution to both 
problems, that of obtaining a higher uniform efficiency, and saving on cost of materials, was offered by the tank-mixture method.

In the development of this method an available supply of the proper type of oil and spreader was required and, most difficult of all, the agitation necessary to give a uniform mixture in the spray tank had to be developed. Through the coöperation of four major oil refineries, a supply of oil was made available. Careful laboratory and field tests soon

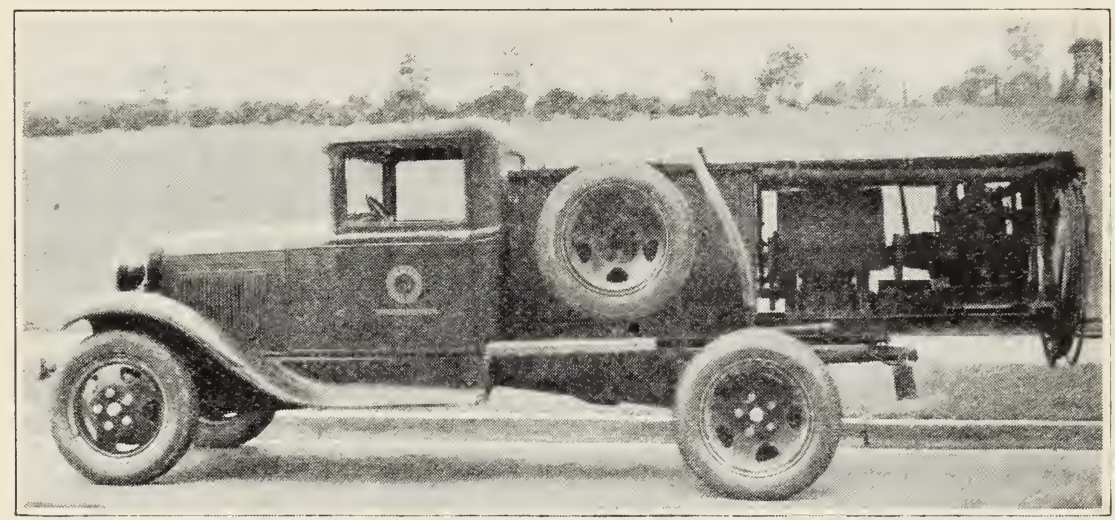

Fig. 1-The University of California Agricultural Experiment Station spray equipment used in this investigation.

showed that blood albumin spreader used in southern California was the best spreader.

The matter of procuring adequate agitation in the comparatively low-powered spray equipment of our deciduous orchards was a problem. The high speed (200 r.p.m.) agitation, as recommended in the citrus orchards, was excellent for equipment with 8-hp. motors or above, but to add this $1 / 2$-hp. requirement for agitation to the outfits using 3 or 4-hp. motors and yet maintain a satisfactory pressure at the pump was almost impossible. The solution of this problem was found in changing the type of agitators in the spray tank, as is shown in the section "Spray-Tank Agitation."

\section{THE TANK-MIXTURE METHOD}

The following procedure shows the difference in the use of commercial oil emusions and the tank-mixture method: Instead of buying the emulsion in the paste form in steel drums and adding it in proper proportions to the water in the spray tank, the grower buys the spreader and spray oil and adds them separately to the water in the spray tank, and a uniform mixture is produced and maintained by the agitators. 
The usual method employed is to fill the tank with water up to, or above, the agitator shaft, start the motor and agitation, sift in the spreader, and add the oil as the tank is filling with water. Proper agitation is essential and no sprayer should be used until the requirements given under "Spray-Tank Agitation" have been met.

The advantages of the tank-mixture method are that it is possible to obtain materials of definite known quality, purchased upon specification, free from blends, and at a saving of approximately 50 per cent in cost. The oil-depositing property of tank-mix spray is higher than that of the commercial oil emulsions and, therefore, a lower dosage may be used. The ease and accuracy in measuring and handling the materials appeals to most growers, and the spreading and wetting properties of the spray are equal, or superior, to those of any commercial oil emulsion.

A comparison of the costs for dormant spraying for the season of 1932-33, as recommended for San Jose seale control is shown below :

Commercial oil emulsion:

5 gallons emulsion per 100 gallons dilute spray at $\$ 0.18 \ldots \ldots \ldots . \$ 0.900$

Tank-mixed method:

3 gallons oil per 100 gallons dilute spray at $\$ 0.10 . . \$ 0.300$

4 ounces spreader per 100 gallons dilute spray...... $0.055 \quad \$ 0.355$

Saving per 100 gallons dilute spray...................................... $\$ 0.545$

Another important factor is that the tank-mixture spray is compatible in combination with bordeaux mixture, or lime-sulfur, or caustic soda. This makes possible a combination spray which may serve a dual purpose. Tank-mix spray is apparently not affected by the hardness of spray water.

\section{OILS EMPLOYED}

In the orchard experiments conducted the past two seasons with the tank-mixture method, three types of nonblended (straight-cut) dormant oils were employed to determine comparative values for scale kill and possible injury to fruit buds. These oils were:

\begin{tabular}{|c|c|c|}
\hline Grade & $\begin{array}{l}\text { Unsulfonated } \\
\text { residue }\end{array}$ & $\begin{array}{l}\text { Viscosity } \\
\text { Saybolt at } 100^{\circ} \text { Fahrenheit }\end{array}$ \\
\hline Brown Neutral ....... & .... $55-65$ & $100-110$ seconds \\
\hline Tank Mix Grade B.. & $65-70$ & $100-120$ seconds \\
\hline Tank Mix Grade A & .... $70-75$ & $100-120$ seconds \\
\hline
\end{tabular}

Blends of other oils were made to give viscosities of $70,120,140,160$, and 200 seconds Saybolt at $100^{\circ}$ Fahrenheit.

No injury to the fruit buds of apple, pear, or prune was noted from the application of any of the oils used except on prune, where the two liigher viscosity blends (160-200 seconds) when applied late delayed the blooming time fully one week. 
No appreciable difference was noted in the control of San Jose scale or brown apricot scale (Lecanium corni Bouche) in any of the applications with oils of from 100 to 120 seconds viscosity.

The results thus far obtained permit recommending the Tank Mix Grade A oil of 70 per cent or above in unsulfonated residue and with a viscosity of from 100 to 120 seconds Saybolt $100^{\circ}$ Fahrenheit for all dormant tank-mixture work. Spray oils of these specifications are available from the following oil companies:

Associated Oil Co. Avon 100 Spray Oil

Shell Oil Co. Dormant Spray Oil No. 11

Standard Oil Co. Calol Dormant Spray Oil Union Oil Co. Dormant Spray Oil 3-110-70

\section{SPREADER FOR THE TANK-MIXTURE SPRAY}

In the earlier attempts at emulsifying dormant oils a calcium caseinate spreader was used. With proper agitation the emulsification and spread are fairly satisfactory, but when hard water is encountered, emulsification becomes impossible. Many places in northern California where hard water occurs, the calcium caseinate spreader cannot be safely recommended. This spreader has also been found to have a tendency to build up too heavy an oil film over comparatively long exposures, which makes its use dangerous under some conditions on such crops as apricot and peach.

Many types of spreaders have been studied for spread and oil-depositing properties in the laboratory, but none have as yet been found to equal the powdered blood albumin. Powdered blood albumin spreader is composed of 1 part Grade A powdered blood albumin of a definite high solubility and 3 parts of a suitable diatomaceous or finely ground earth. The spreader is used at the rate of 4 ounces to 100 gallons of spray. This past season it has been obtained in glassine-lined bags in two convenient sizes from manufacturers in Oakland and San Francisco. The 8-ounce package, sufficient for a 200-gallon tank sold at 11 cents a package, and the 12-ounce package, sufficient for a 300-gallon tank sold at 16 cents a package. It is inadvisable for anyone but a properly equipped manufacturer to prepare this spreader.

\section{SPRAY-TANK AGITATION}

Effective agitation is a requisite of primary importance in the use of most sprays. In using even the most stable commercial oil emulsions conditions are sometimes encountered where, owing to the breaking of the emulsion in hard water, or to the interruption of the spraying before the tank is emptied, the oil may become concentrated at the surface of 
the water. Also in the use of insoluble insecticides, such as powdered lead arsenate and sulfur, sufficient agitation is important in order that a uniform concentration may be obtained. The agitation requirement prescribed for tank-mix spray assures that a uniform mixture will be had under all conditions.

In testing something over 200 sprayers in the field it was found that very few have adequate agitation, owing largely to the comparatively slow speed of the agitator shaft and to the propeller type of agitators

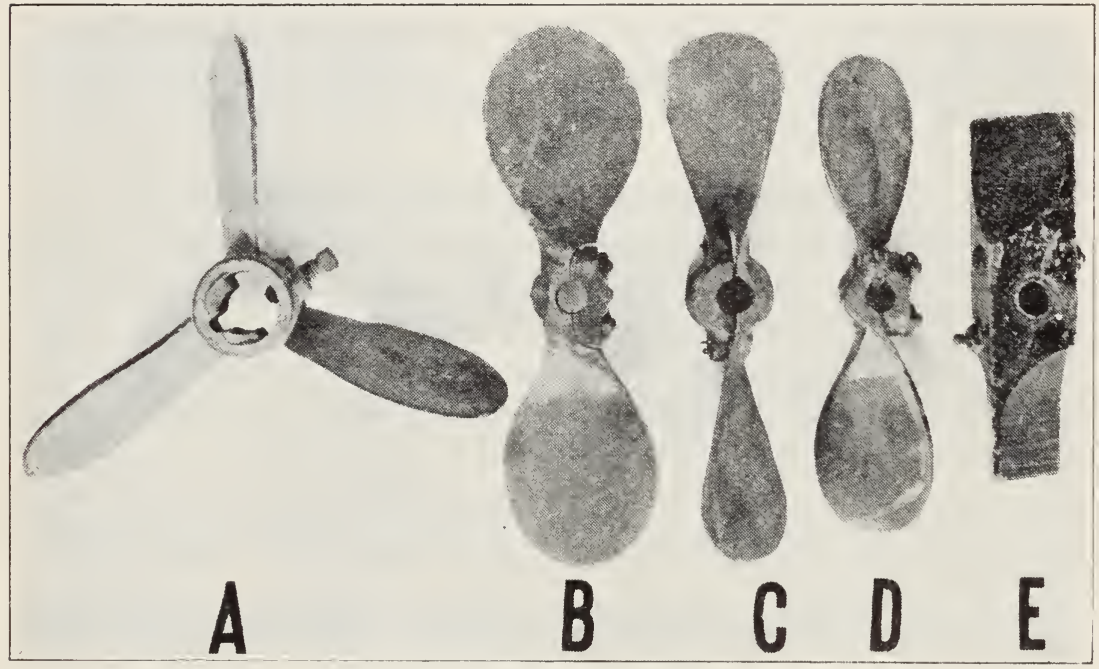

Fig. 2.-Different propeller types of agitators found in spray tanks in northern California. Agitators C, D, and E are not satisfactory with oil sprays.

(fig. 2). In Bulletin 527, ${ }^{4}$ it has been shown that a uniform mixture may be obtained by increasing the speed of the shaft to 200 r.p.m. and using the proper kind and number of propeller-type agitators. The energy consumption is approximately $1 / 2 \mathrm{hp}$. This high-speed agitation is practicable with sprayers having 8-hp. motors, or over, and can be obtained by simply changing the ratio of the gears between the pump and agitator shaft.

In northern California a large percentage of the sprayers are equipped with tanks of 100, 200, or 300-gallon capacity, and with motors of $2 \frac{1}{2}$, $3,4,6$, and $8 \mathrm{hp}$. A few sprayers have 300 and 400-gallon tanks and 12 or 15-hp. motors. The normal speed of the agitator shaft on the different makes of equipment varies widely. It is important to know this speed before making any changes in the agitators. This may be readily deter-

4 Smith, Ralph H. The tank-mixture method of using oil spray. California Agr. Exp. Sta. Bul. 527:1-84. Reprinted 1933. 
mined by simply counting the revolutions of the sprocket at the end of the shaft outside the tank.

Investigations made in the orchards and in the laboratory of the Division of Agricultural Engineering at Davis have shown that adequate agitation cannot be obtained with the use of the propeller-type agitators (table 2), at speeds of from 100 to 120 r.p.m., and it is impracticable to employ the high-speed agitation on the low-powered sprayers. Accordingly, a new type flat square-end agitator (fig. 3) has been developed, which, in 100, 200, and 300-gallon tanks, will give uniform mixtures with an energy consumption of less than $1 / 5 \mathrm{hp}$.

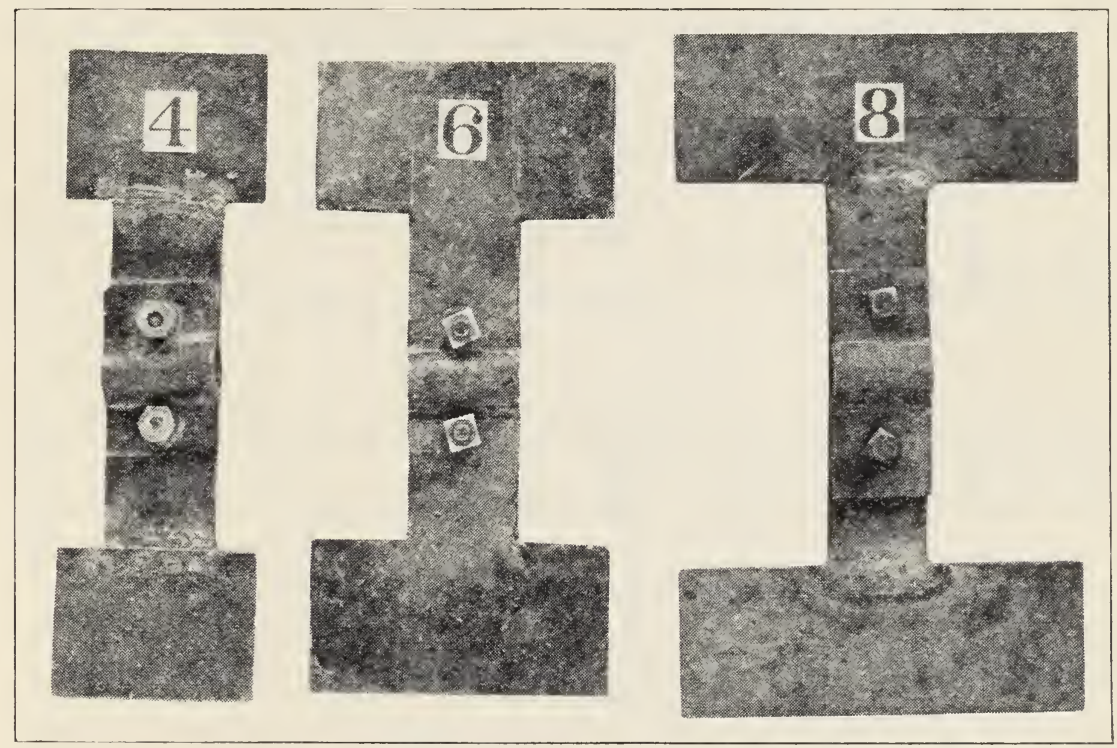

Fig. 3.-The new flat square-end agitators which should replace the propeller types of agitators in all spray tanks.

This new agitator is made of $3 / 16^{-i n c h}$ mild steel from 2 -inch and 3 -inch band material. The tips may be either welded or riveted on. The 13-inch length (fig. 4) is for tanks having the agitator shaft about 7 inches above the bottom of the tank and is to be run at speeds of from 95 to 110 r.p.m. Similarly patterned agitators 10 inches in length may be employed in tanks having the agitator shaft about $51 / 2$ inches above the bottom of the tank at speeds of 140 to 150 r.p.m. Four of the agitators 10 inches in length, at a speed of 100 r.p.m., require approximately the same amount of energy as four of the 10-inch agitators running at a speed of 140 r.p.m.

The first three tests in table 2 are with propeller-type agitators, and 
show the lack of uniformity in the mixture. The next three tests with the new flat, square-end agitators show uniform mixtures. The last three tests, in which two of the new flat, square-end agitators are used in combination with two propeller-type agitators, show that a speed of 100 to 110 r.p.m. is required. In all tests the tank was filled with water, and

TABLE 2

Results of Agitator Tests, Using Only Oil and Water

\begin{tabular}{|c|c|c|c|c|c|c|c|c|c|c|c|}
\hline \multirow{3}{*}{ Make } & \multirow{3}{*}{$\begin{array}{l}\text { Spray- } \\
\text { tank } \\
\text { capac- } \\
\text { ity, in } \\
\text { gallons }\end{array}$} & \multirow{3}{*}{$\begin{array}{l}\text { Depth, } \\
\text { in } \\
\text { inches }\end{array}$} & \multirow{3}{*}{$\begin{array}{l}\text { Length, } \\
\text { in } \\
\text { inches }\end{array}$} & \multicolumn{4}{|c|}{ Agitators } & \multicolumn{4}{|c|}{$\begin{array}{c}\text { Number of gallons in tank when } \\
\text { samples were taken }\end{array}$} \\
\hline & & & & Num- & Type* & Size & $\begin{array}{l}\text { Speed, } \\
\text { in }\end{array}$ & 300 & 200 & 100 & 10 \\
\hline & & & & & & & & \multicolumn{4}{|c|}{ Per cent of oil in sample } \\
\hline
\end{tabular}

Propeller-ty pe agitators

\begin{tabular}{l|l|l|l|l|l|l|l|l|l|l|l}
\hline Bean & 200 & 28 & 52 & 2 & A & large & 98 & $\ldots .$. & 0.3 & 0.9 & 1.8 \\
Hardie & 200 & 33 & 44 & 2 & B & large & 150 & $\ldots .$. & 0.0 & 0.1 & 1.9 \\
Bean & 300 & 33 & 64 & 3 & A & large & 90 & 0.1 & 0.1 & 1.0 & 1.8 \\
\hline
\end{tabular}

New flat, square-end agitators

\begin{tabular}{l|l|l|l|l|l|l|l|l|l|l|l}
\hline Bean & 200 & 28 & 52 & 4 & Flat & 4-inch & 90 & $\ldots \ldots$ & 1.0 & 1.0 & 1.0 \\
Hardie & 200 & 33 & 44 & 4 & Flat & 4 -inch & 99 & $\ldots \ldots$ & 1.0 & 1.0 & 1.0 \\
Bean & 300 & 33 & 64 & 4 & Flat & 8-inch & 96 & 0.9 & 10 & 1.0 & 1.1 \\
\hline
\end{tabular}

Combinations of new flat agitators and propeller types

\begin{tabular}{|c|c|c|c|c|c|c|c|c|c|c|c|}
\hline Hardie & 200 & 33 & 44 & $\begin{array}{l}2 \\
2\end{array}$ & $\begin{array}{c}\text { A } \\
\text { Flat }\end{array}$ & $\begin{array}{l}\text { large } \\
4 \text {-inch }\end{array}$ & $\{100$ & $\ldots \ldots$. & 1.0 & 1.0 & 10 \\
\hline Hardie & 200 & 33 . & 44 & $\begin{array}{l}2 \\
2\end{array}$ & $\begin{array}{c}\text { B } \\
\text { Flat }\end{array}$ & $\begin{array}{l}\text { large } \\
4 \text {-inch }\end{array}$ & \}$^{96}$ & $\ldots \ldots$. & 0.7 & 1.0 & 1. 2 \\
\hline Hardie & 200 & 33 & 44\{ & $\begin{array}{l}2 \\
2\end{array}$ & $\begin{array}{c}\text { B } \\
\text { Flat }\end{array}$ & $\begin{array}{l}\text { large } \\
\text { 4-inch }\end{array}$ & $\{110$ & $\ldots \ldots$ & 1.0 & 1.0 & 1.0 \\
\hline
\end{tabular}

* Type letters " $\mathrm{A}$ " and " $\mathrm{B}$ " refer to the propeller-type agitators shown in figure 2.

dyed kerosene was poured on the surface. The agitators were then started, and after running for 1 minute, the spray nozzles were opened and samples were taken at intervals during the emptying of the tank.

Since the dimensions of spray tanks are not uniform, caution should be used in obtaining sufficient agitation. Tanks differ particularly in their length and depth. It is advised that a test be made after the suggested number of agitators have been installed. The Farm Advisor or Agricultural Commissioner, will assist in this test. 
In tanks having the agitator shaft 7 inches above the bottom and of 100 and 200-gallon capacity, with a speed on the agitator shaft of 95 to 110 r.p.m., four of the 13 -inch agitators with 4-inch tips are recommended. In tanks of 300-gallon capacity, with a speed on the agitator shaft of 95 to 110 r.p.m., four of the 13-inch agitators with 8-inch tips are recommended. In 400-gallon capacity tanks, which usually have more than 8-hp. motors, it is better to resort to a higher speed on the
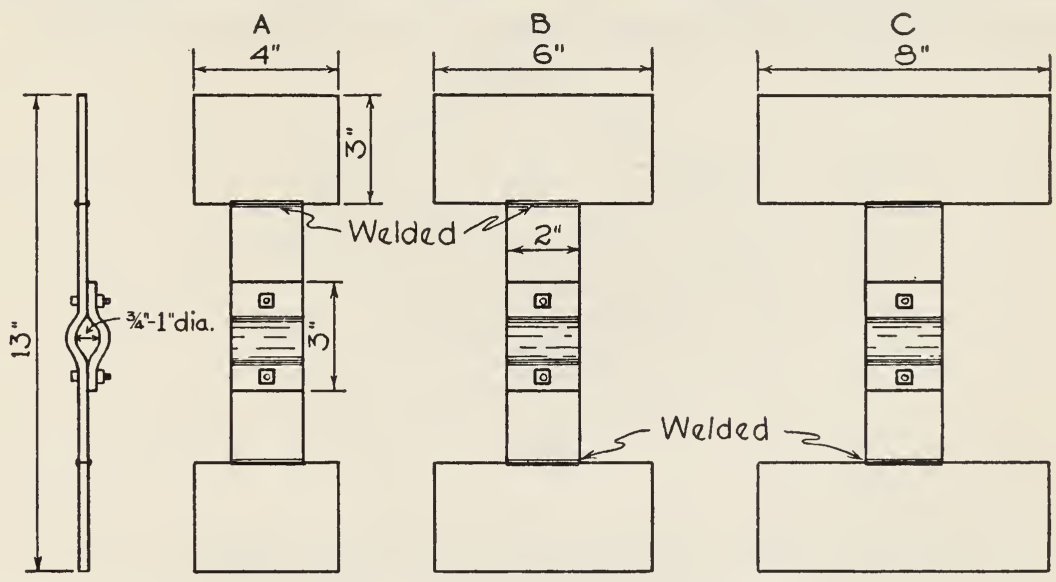

Fig. 4.-Patterns for the new, flat square-end agitators recommended in this bulletin.

agitator shaft, though four of the 8-inch tip agitators with a speed of 120 r.p.m., or above, are adequate.

In tanks having the agitator shaft about $5 \frac{1}{2}$ inches above the bottom and of 100 and 200-gallon capacity, with a speed on the agitator shaft of 140-150 r.p.m., four of the 10-inch agitators with 4-inch tips are required. In tanks of 300-gallon capacity four of the 8-inch tip agitators at the same speed are sufficient.

Two of the agitators should be placed as near the ends of the tank as possible and the other two spaced evenly between the end agitators. They may be set at right angles to each other or all four parallel.

It has also been found possible to combine the new flat agitators with certain of the larger propeller-type 3-bladed (fig. $2 A$ ) and 2-bladed (fig. $2 \mathrm{~B}$ ) agitators and obtain satisfactory results, as is shown in table 2. Two 3-bladed (fig. $2 A$ ) agitators or two large 2-bladed (fig. $2 B$ ) agitators and the two 13-inch new flat agitators with 4 -inch tips at 110 r.p.m. gave a uniform mixture in 200-gallon tanks.

In certain underslung tanks which have the agitator shaft set at an angle the blade-type agitators present are usually adequate if running at a sufficient speed (140 r.p.m.). If not, however, a flat agitator can be designed to fit the different depths in the tank. 
In most spray tanks there is a splash or filler box, with a screen which fits down into the opening of the tank. This usually extends 5 or 6 inches below the top of the tank and materially interferes with the obtaining of a uniform mixture when the tank is full, especially with the low-speed agitation. Also any cleats on the inside of the tank and cooling pipes check the agitation. A much more practical type of filler box may be constructed (fig. 5) which does not extend down into the tank and yet permits filling, testing the tank when full, and prevents splashing.
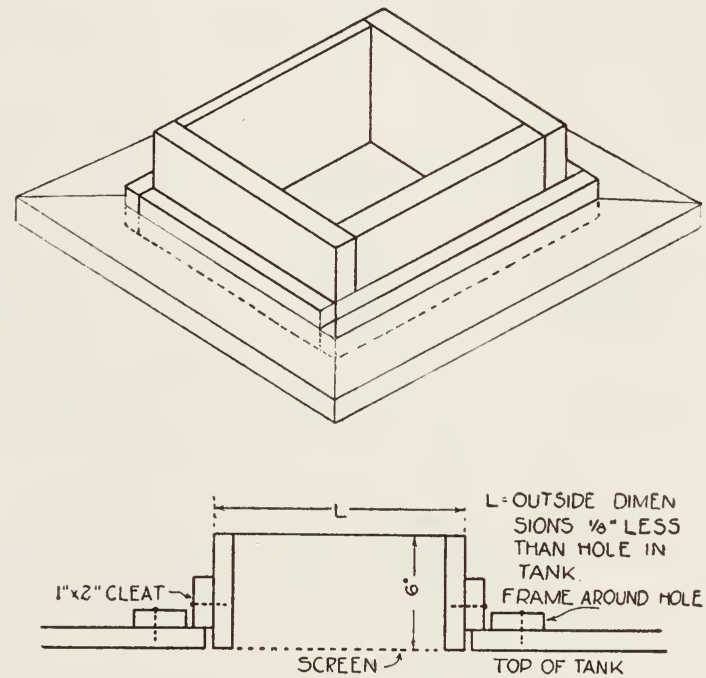

Scale $1^{n=}=6^{n}$

CROSS SECTION

JPF $8 / 9 / 33$

Fig. 5.-A more practical type of filler box for spray tanks, which does not interfere with agitation.

\section{ORCHARD EXPERIMENTS IN THE SEASON OF 1931-32}

During the winter spray season of 1931-32 over 4,000 gallons of dilute tank-mixture sprays were applied on several varieties of apples, Bartlett pears, and prunes on experimental plots in the control of San Jose scale and brown apricot scale. Spray oils of viscosities of 100, 120, 140, 160 , and 200 seconds were employed at dosages of 3,4 , and 5 gallons per 100 gallons of dilute spray. The amount of spreader was varied from no spreader to $4,6,8$, and 10 ounces per 100 gallons. As a comparative check some of the standard commercial oil emulsions were used at recommended dosages on each orchard sprayed. Counts of the San Jose scale were made at harvest time on approximately 1,000 to 3,000 apples per plot. Counts were made of brown apricot scale six weeks after the applications. Some of the data obtained are given in tables 3 and 4.

The data presented in table 3 indicate that the most effective control 
TABLE 3

Control of San Jose Scale on Apple, Season of 1931-32

(Spray applications made January 26 and February 26)

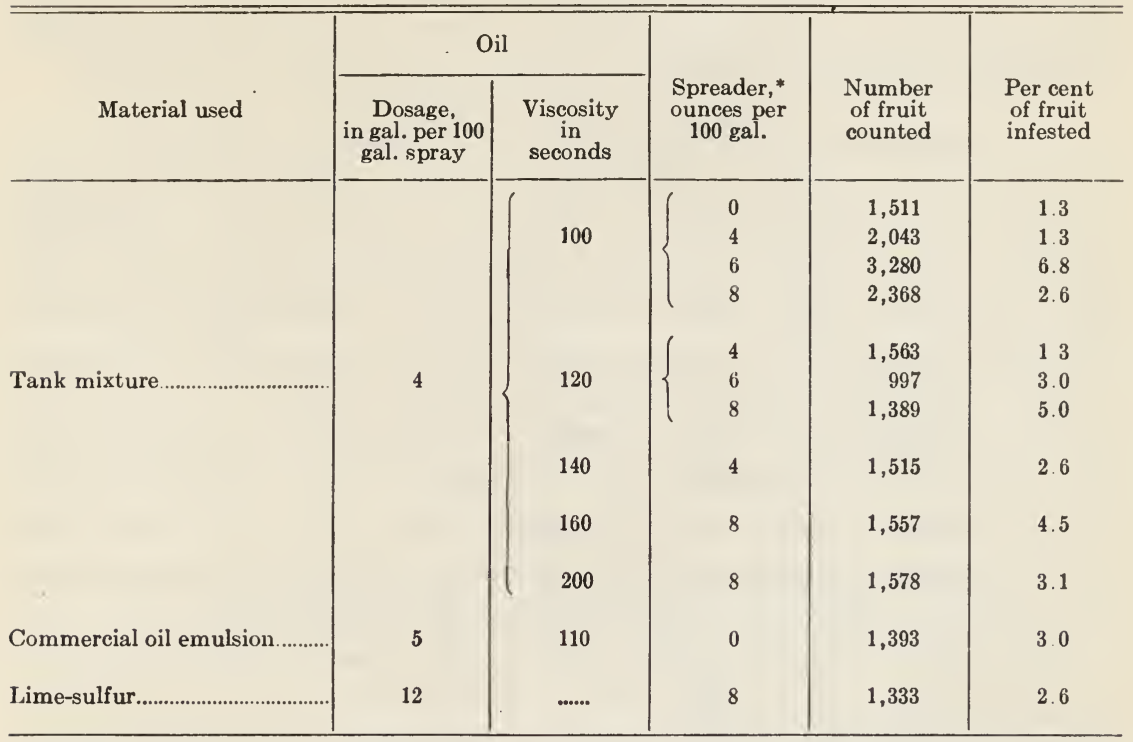
latter.

* Blood albumin spreader is used in all cases except for lime-sulfur; calcium caseinate is used for the

TABLE 4

Control of Brown A pricot Scale on Prune, Season of 1931-32

(Spray applications made January 26 and February 26)

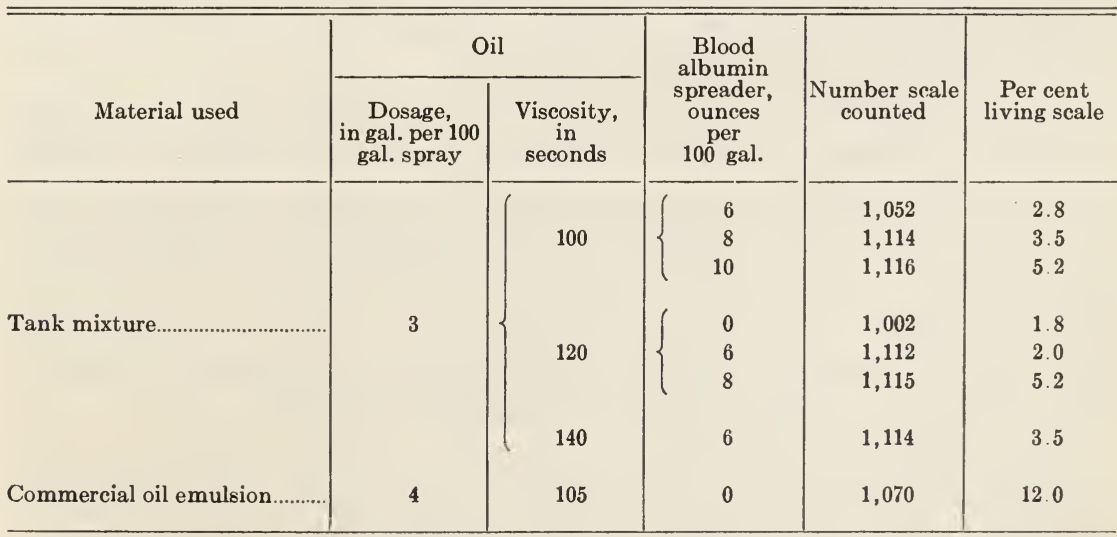

of the San Jose scale was obtained with the oils of 100 and 120 seconds viscosity and with 4 ounces of blood albumin spreader. Where no spreader was used the coverage was unsatisfactory. No difference was noted in the blooming time of the apples or pears on any of the spray plots where oils of different viscosities had been used. 
In the control of brown apricot scale on prune, the best results were obtained with the lower dosage of spreader and with oils of 100 and 120 seconds viscosity. With late applications, the oils of 140 seconds viscosity and above delayed the bloom of prunes fully 10 to 14 days. January sprays are preferable to sprays applied late in February.

\section{ORCHARD EXPERIMENTS IN THE SEASON OF 1932-33}

During the spray season, 1932-33 over 7,500 gallons of dilute spray were applied experimentally on apricots, prunes, apples, and pears. Dosages for San Jose scale, brown apricot scale, fruit tree leaf roller eggs, and brown mite eggs were determined. Combination sprays of bordeaux mixture and the tank-mixture spray were applied to apricots in the "pink bud" stage, for control of brown rot and fruit tree leaf roller. The stimulation effect of different oils applied at monthly intervals on prunes was studied. The experiments were conducted in ten widely separated orchards of the coastal area, and in each orchard one or more standard commercial oil emulsions were used for comparison. Oils of three grades and viscosities from 70 to 140 seconds were used.

Scale counts were made about eight weeks after the applications, by counting all scale on 5 twigs-12 to 15 inches long-taken from each of 20 trees in each spray plot. Tables 5 to 11 give some of the data obtained.

\section{RESULTS OF 1932-33 ORCHARD EXPERIMENTS}

In the control of San Jose scale it has been well demonstrated that where the bark is not rough and the scale not encrusted a dosage of 3 gallons of Tank Mix Grade A oil and 4 ounces of blood albumin spreader per 100 gallons of dilute spray is sufficient.

The brown apricot scale on prunes is comparatively easy to kill until it begins to develop wax. In the early season, this scale on prunes usually can be killed with a comparatively low dosage, while late in February it becomes more difficult. On apricot, growth is usually faster than on prune, and a higher dosage is required. Where bordeaux mixture is combined with oil sprays on apricots and used as late as the "pink bud" stage, the scale is not only more difficult to kill, but the effectiveness of the oil is reduced, and the oil dosage must be increased.

The standard recommendation for the spraying of fruit tree leaf roller eggs has been 7 gallons of commercial oil emulsion per 100 gallons of dilute spray. Experiments in 1932-33 have amply shown that on prune and apricot satisfactory control can be obtained by the tank-mix method with a dosage of 4 gallons of oil and 4 ounces of blood albumin spreader per 100 gallons of dilute spray. The practicability of combining bordeaux mixture with the oil emulsion to be applied in the "pink bud" stage on apricots has been demonstrated. 
TABLE 5

San Jose Scale Control on Apple, Season of 1932-33 (Spray applications made March 1, 1933)

\begin{tabular}{|c|c|c|c|c|c|}
\hline \multirow[b]{2}{*}{ Material used } & \multicolumn{2}{|c|}{ Oil } & \multirow{2}{*}{$\begin{array}{c}\text { Blood } \\
\text { albumin } \\
\text { spreader, } \\
\text { ounces } \\
\text { per } \\
100 \text { gal. }\end{array}$} & \multirow{2}{*}{$\begin{array}{c}\text { Number scale } \\
\text { counted }\end{array}$} & \multirow{2}{*}{$\begin{array}{l}\text { Per cent } \\
\text { living scale }\end{array}$} \\
\hline & $\begin{array}{l}\text { Dosage, } \\
\text { in gal. per } 100 \\
\text { gal. spray }\end{array}$ & $\begin{array}{l}\text { Viscosity, } \\
\text { in } \\
\text { seconds }\end{array}$ & & & \\
\hline \multirow{3}{*}{ Tank mixture } & 4 & 110 & 4 & 204 & 0.0 \\
\hline & 3 & 110 & 4 & 191 & 0.0 \\
\hline & 2 & 110 & 4 & 131 & 0.8 \\
\hline Commercial oil emulsion B... & 4 & 105 & 0 & 266 & 0.4 \\
\hline \multirow[t]{2}{*}{ Tank mixture } & 4 & 110 & 4 & 256 & 0.0 \\
\hline & 4 & 70 & 4 & 230 & 0.0 \\
\hline Commercial oil emulsion $\mathrm{A}$....... & 4 & 105 & 0 & 366 & 00 \\
\hline
\end{tabular}

TABLE 6

Control of Brown Apricot Scale on Prune, Season of 1932-33

(Spray applications made February 10, 11, 1933)

\begin{tabular}{|c|c|c|c|c|c|}
\hline \multirow[b]{2}{*}{ Material used } & \multicolumn{2}{|c|}{ Oil } & \multirow{2}{*}{$\begin{array}{c}\text { Blood } \\
\text { albumin } \\
\text { spreader, } \\
\text { ounces } \\
\text { per } \\
100 \text { gal. }\end{array}$} & \multirow{2}{*}{$\begin{array}{c}\text { Number scale } \\
\text { counted }\end{array}$} & \multirow{2}{*}{$\begin{array}{c}\text { Per cent } \\
\text { living scale }\end{array}$} \\
\hline & $\begin{array}{l}\text { Dosage, } \\
\text { in gal. per } 100 \\
\text { gal. spray }\end{array}$ & $\begin{array}{l}\text { Viscosity, } \\
\text { in } \\
\text { seconds }\end{array}$ & & & \\
\hline \multirow{3}{*}{ Tank mixture } & 3 & 110 & 4 & 2,576 & 0.4 \\
\hline & 2 & 110 & 4 & 2,644 & 1.3 \\
\hline & 1 & 110 & 4 & 1,251 & 1.0 \\
\hline \multirow{3}{*}{ Commercial oil emulsion $A^{*} \ldots$} & 4 & 105 & 0 & 2,044 & 0.4 \\
\hline & 3 & 105 & 0 & 1,581 & 0.5 \\
\hline & 2 & 105 & 0 & 1,444 & 0.9 \\
\hline \multirow[t]{2}{*}{ Commercial oil emulsion $\mathrm{B} \nmid \ldots .}$. & 4 & 110 & 0 & 1,726 & 0.6 \\
\hline & 3 & 110 & 0 & 1,239 & 1.2 \\
\hline
\end{tabular}

* Commercial oil emulsion $\mathrm{A}$ is classed as one with relatively high oil deposit.

$\dagger$ Commercial oil emulsion B is one with relatively low oil deposit.

\section{TABLE 7}

Control of Brown Apricot Scale on Apricot, Season of 1932-33 (Spray applications made February 8, 1933)

\begin{tabular}{|c|c|c|c|c|c|}
\hline \multirow[b]{2}{*}{ Material used } & \multicolumn{2}{|c|}{ Oil } & \multirow{2}{*}{$\begin{array}{c}\text { Blood } \\
\text { albumin } \\
\text { spreader, } \\
\text { ounces } \\
\text { per } \\
100 \text { gal. }\end{array}$} & \multirow{2}{*}{$\begin{array}{l}\text { Number scale } \\
\text { counted }\end{array}$} & \multirow{2}{*}{$\begin{array}{c}\text { Per cent } \\
\text { living scale }\end{array}$} \\
\hline & $\begin{array}{l}\text { Dosage, } \\
\text { in gal. per } 100 \\
\text { gal. spray }\end{array}$ & $\begin{array}{l}\text { Viscosity, } \\
\text { in } \\
\text { seconds }\end{array}$ & & & \\
\hline \multirow{3}{*}{ Tank mixture } & 3 & 100 & 4 & 1,039 & 0.1 \\
\hline & $2 \frac{1}{2}$ & 120 & 4 & 1,340 & 3.2 \\
\hline & 3 & 70 & 4 & 852 & 0.5 \\
\hline Commercial oil emulsion.......... & 4 & 105 & 4 & 906 & 0.8 \\
\hline
\end{tabular}


TABLE 8

Control of Brown Apricot Scale on Apricot When Combined Spray* is Used, SEASON OF 1932-33

(Spray applications made February 27, 1933)

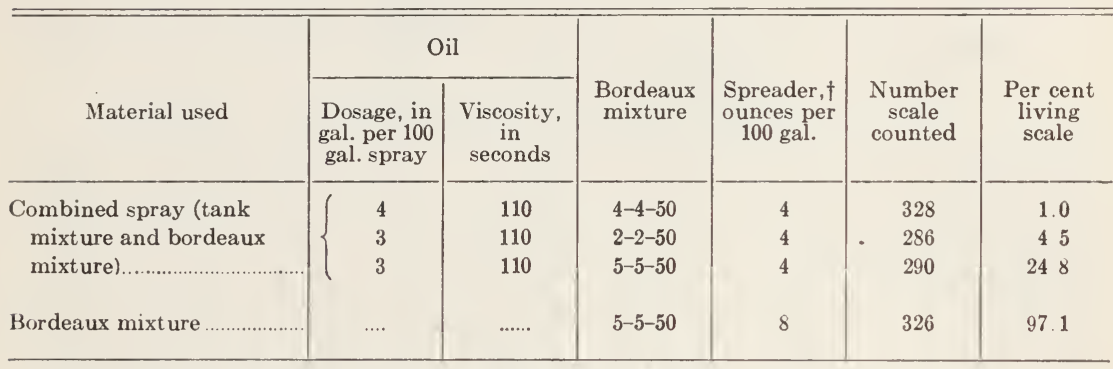

* Bordeaux mixture is used for control of brown rot on apricot.

† Blood albumin spreader is used in all cases except for bordeaux mixture; calcium caseinate is used for the latter.

\section{TABLE 9}

Spraying of Fruit Tree leaf Roller Egg Masses on Apricot, Season of 1932-33 (Spray applications made February 21-23, 1933)

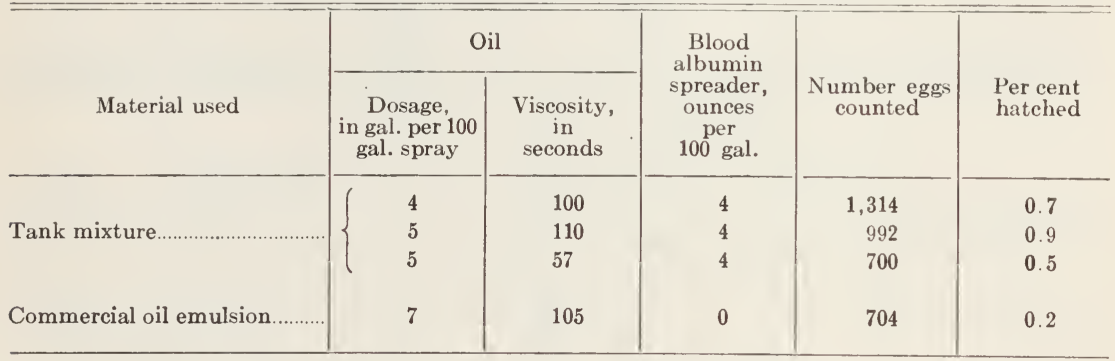

\section{TABLE 10}

Sprating of Fruit Tree Leaf Roller Egg Masses on Blenheim Apricot

When Combined Spray* is Used, Season of 1932-33 (Spray applications made February 25, 1933, in "pink bud" stage)

\begin{tabular}{|c|c|c|c|c|c|c|}
\hline \multirow[b]{2}{*}{ Material used } & \multicolumn{2}{|c|}{ Oil } & \multirow[b]{2}{*}{$\begin{array}{l}\text { Bordeaux } \\
\text { mixture }\end{array}$} & \multirow[b]{2}{*}{$\begin{array}{l}\text { Spreader, } \dagger \\
\text { ounces per } \\
100 \text { gal. }\end{array}$} & \multirow[b]{2}{*}{$\begin{array}{l}\text { Number } \\
\text { eggs } \\
\text { counted }\end{array}$} & \multirow[b]{2}{*}{$\begin{array}{l}\text { Per cent } \\
\text { hatched }\end{array}$} \\
\hline & $\begin{array}{l}\text { Dosage, in } \\
\text { gal. per } 100 \\
\text { gal. spray }\end{array}$ & $\begin{array}{l}\text { Viscosity, } \\
\text { in } \\
\text { seconds }\end{array}$ & & & & \\
\hline $\begin{array}{l}\text { Combined spray (tank mix- } \\
\text { ture and bordeaux mix- } \\
\text { ture) }\end{array}$ & $\begin{array}{l}5 \\
4 \\
3\end{array}$ & $\begin{array}{l}100 \\
100 \\
100\end{array}$ & $\begin{array}{l}2-2-50 \\
4-4-50 \\
5-5-50\end{array}$ & $\begin{array}{l}4 \\
4 \\
4\end{array}$ & $\begin{array}{l}1,934 \\
1,807 \\
2,026\end{array}$ & $\begin{array}{l}0.6 \\
0.7 \\
1.4\end{array}$ \\
\hline Bordeaux mixture........ & $\ldots$. & $\ldots \ldots$ & $5-5-50$ & 8 & 1,501 & 97.1 \\
\hline
\end{tabular}

* Bordeaux mixture is used for control of brown rot on apricot.

$\dagger$ Blood albumin spreader is used in all cases except for bordeaux mixture; in the latter case calcium caseinate is used. 
TABLE 11

EfFect of Four Different Dormant Oil Sprays on the Condition OF BLOOM AT VARIOUS DATES OF OBSERVATION

(Dosage rate $=3$ gallons oil per 100 of spray)

\begin{tabular}{|c|c|c|c|c|c|c|}
\hline \multirow{2}{*}{ Oil } & \multirow{2}{*}{$\begin{array}{l}\text { Date of } \\
\text { application }\end{array}$} & \multicolumn{5}{|c|}{ Condition of bloom } \\
\hline & & March 12 & March 19 & March 22 & March 28 & April 4 \\
\hline \multirow{3}{*}{$\begin{array}{l}\text { Brown } \\
\text { Neutral } \\
\text { oil }\end{array}$} & Jan. 13 & Green bud & $\begin{array}{l}10 \text { per eent } \\
\text { white bud }\end{array}$ & $\begin{array}{l}\text { White bud, } \\
\text { some open }\end{array}$ & $1 / 3$ full bloom & Full bloom \\
\hline & Feb. 9 & $\begin{array}{l}\text { Some green } \\
\text { bud }\end{array}$ & Green bud & $\begin{array}{l}\text { White bud, } \\
\text { none open }\end{array}$ & $1 / 4$ full bloom & Full bloom \\
\hline & Mar. 9 & $\begin{array}{l}\text { Some green } \\
\text { bud }\end{array}$ & Green bud & Green bud & $*$ & $\begin{array}{l}50 \text { per cent } \\
\text { full bloom }\end{array}$ \\
\hline \multirow{3}{*}{$\begin{array}{l}\text { Tank Mix, } \\
\text { Grade B, } \\
70 \text { seconds } \\
\text { viscosity }\end{array}$} & Jan. 13 & Green bud & $\begin{array}{l}20 \text { per cent } \\
\text { white bud }\end{array}$ & $\begin{array}{l}\text { White bud, } \\
\text { some open }\end{array}$ & $2 / 3$ full bloom & $\begin{array}{l}\text { Past full } \\
\text { bloom }\end{array}$ \\
\hline & Feb. $\quad 9$ & Green bud & $\begin{array}{l}\text { Green bud, } \\
\text { few white }\end{array}$ & $\begin{array}{l}\text { White bud, } \\
\text { some open }\end{array}$ & $1 / 4$ full bloom & $\begin{array}{l}\text { Nearly full } \\
\text { bloom }\end{array}$ \\
\hline & Mar. 9 & $\begin{array}{l}\text { Some green } \\
\text { bud }\end{array}$ & Green bud & Green bud & $*$ & $\begin{array}{l}80 \text { per cent } \\
\text { full bloom }\end{array}$ \\
\hline \multirow{4}{*}{$\begin{array}{l}\text { Tank Mix, } \\
\text { Grade B, } \\
100 \text { seconds } \\
\text { viseosity }\end{array}$} & Jan. 13 & Green bud & $\begin{array}{l}10 \text { per cent } \\
\text { white bud }\end{array}$ & $\begin{array}{l}\text { White bud, } \\
\text { some open }\end{array}$ & $2 / 3$ full bloom & $\begin{array}{l}\text { Past full } \\
\text { bloom }\end{array}$ \\
\hline & Feb. 9 & Green bud & $\begin{array}{l}\text { Green bud, } \\
\text { few white }\end{array}$ & $\begin{array}{l}\text { White bud, } \\
\text { few open }\end{array}$ & $1 / 2$ full bloom & Full bloom \\
\hline & Mar. 9 & $\begin{array}{l}\text { Some green } \\
\text { bud }\end{array}$ & Green bud & Green bud & $*$ & $\begin{array}{l}50 \text { per cent } \\
\text { full bloom }\end{array}$ \\
\hline & Jan. 13 & Green bud & $\begin{array}{l}5 \text { per cent } \\
\text { white bud }\end{array}$ & $\begin{array}{l}\text { White bud. } \\
\text { very few open }\end{array}$ & $1 / 3$ full bloom & Full bloom \\
\hline $\begin{array}{l}\text { Tank Mix, } \\
\text { Grade A, } \\
100 \text { seconds } \\
\text { viscosity }\end{array}$ & Feb. $\quad 9$ & $\begin{array}{l}\text { Some green } \\
\text { bud }\end{array}$ & Green bud & $\begin{array}{l}\text { White bud, } \\
\text { none open }\end{array}$ & $1 / 4$ full bloom & Full bloom \\
\hline & Mar. 9 & $\begin{array}{l}\text { Some green } \\
\text { bud }\end{array}$ & Green bud & Green bud & $*$ & $\begin{array}{l}50 \text { per cent } \\
\text { full bloom }\end{array}$ \\
\hline sprayed & ; & $\begin{array}{l}\text { Some green } \\
\text { bud }\end{array}$ & Green bud & Green bud & White bud & $\begin{array}{l}80 \text { per cent } \\
\text { full bloom }\end{array}$ \\
\hline
\end{tabular}

* No observations made.

The study of stimulation effect of different oils applied at different times during the dormant period has shown that the greatest stimulation apparently occurs when applications are made early in January. The stimulation is more apparent at the time of the unfolding of the bud than at full-bloom time. The greatest stimulation was noted with an oil of 70 seconds viscosity and about 67 per cent unsulfonated residue. Bud stimulation, though used by some growers to prevent thrips attack and to increase chances of pollination, may or may not be advisable. This depends upon frost conditions at bloom time and thrips emergence. 


\section{DOSAGE RECOMMENDATIONS}

From the above experiments and other field work it is apparent that the following recommendations may safely be made for the use of the tankmixture method in dormant spray applications on deciduous fruit trees.

San.Jose Scale.-In infestations where the bark is relatively smooth and the scale not incrusted, 3 gallons of Tank Mix Grade A oil and 4 ounces of powdered blood albumin spreader per 100 gallons of dilute spray is sufficient. The addition of $1 \frac{1}{2}$ or 2 pounds of caustic soda per 100 gallons of dilute spray may be made where the moss condition on the trees to be sprayed warrants its use.

Brown Apricot Scale.-A dosage of 2 gallons of Tank Mix Grade A oil plus 4 ounces of powdered blood albumin spreader per 100 gallons of dilute spray on prunes is recommended early in the season where the scale is not particularly advanced in development. Later in the season a 3-gallon dosage may be necessary. On apricots the scale usually develops faster and a 3-gallon dosage per 100 is recommended. Where bordeaux mixture is used in combination with the oil spray, a dosage of not less than 4 gallons of oil per 100 gallons of dilute spray should be used on apricots.

Fruit Tree Leaf Roller Egg Masses.-A dosage of 4 gallons of the Tank Mix A Grade oil per 100 gallons of dilute spray is recommended for the fruit tree leaf roller egg masses in the full dormant period. Where bordeaux mixture is to be combined in this spray the dosage should be 5 gallons of oil per 100 gallons of dilute spray.

Brown Mite Eggs.-Eggs of this mite are usually destroyed in any spray program for control of scale. Even 2 gallons of oil per 100 gallons of dilute spray gave perfect control on prunes sprayed while dormant.

\section{SUMMARY}

The tank-mixture method offers to the deciduous fruit growers a practical, economical means of obtaining a dormant spray for deciduous fruit trees. ${ }^{5}$ The saving in cost of material is approximately one-half, and the coverage and oil-depositing properties of this spray are better than any thus far tested.

Proper agitation in the spray tank can readily be obtained by installing a sufficient number of the new flat, square-end agitators.

Over 5,000,000 gallons of dilute spray made by the tank-mixture method were applied by fruit growers to the orchards in six counties in northern California during the season of 1933. No injury has been recorded, and the control has been most satisfactory.

5 'The tank-mixture method may also be employed in the application of foliage or summer-type sprays in the control of thrips, leafhopper, and codling moth in combination with nicotine, and for red spider as a straight oil spray. In these sprays a lower viscosity and higher unsulfonated residue oil is used. Experiments on the effects of these sprays are being completed. 